\title{
Religion, reintegration and rehabilitation in French prisons: The impact of prison secularism
}

\author{
Corinne Rostaing ${ }^{1}$, Céline Béraud ${ }^{2}$ and Claire de Galembert ${ }^{3}$
}

\section{Introduction}

What place can religion have in French prisons, in a country which has defined itself as "laïque", secular since the 1905 law on the Separation of the Churches and State? In order to answer this question, our analysis has endeavoured to focus on religion in its most ordinary forms (Piette 2003), as it is applied and administered in penitentiary institutions. Inspired by the theory of symbolic interactionism, we conducted an in-depth ethnographic study between January 2011 and October 2012, both "from above" (in administrative centres and at the top of religious institutions) and "from below" (in eight French prisons ${ }^{4}$ ), just as much from the point of view of prison administrations, chaplains of all denominations, and prisoners, by observing, among other things, cultural activities or chaplains' visits to cells, and through face to face interviews with prisoners, the Prison Administrations Directorate (members of the directorate, correctional officers, social workers) or other people working in prisons (doctors, trainers, managers, etc).

\footnotetext{
${ }^{1}$ Corinne Rostaing $(*)$

Centre Max Weber (CNRS)

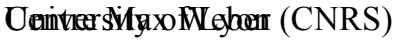

chnineresitostofing@univ-lyon2.fr

corinne.rostaing@univ-lyon2.fr

${ }^{2}$ Céline Béraud(*)

ËAdsie Béraud(*)

EelliteSBeraud@gmail.com

Celine.Beraud@gmail.com

${ }^{3}$ Claire de Galembert(*)

Ecole Normale Supérieure de Cachan

galember@,isp.ens-cachan.fr
}

\footnotetext{
${ }^{4}$ The study, commissioned by the Prisons Administration Directorate and co-financed by Justice International Cooperation (GIP-Justice), was conducted in three jails ("maisons d'arrêt", temporary penitentiaries for people awaiting trial or serving short sentences), two prisons (for convicts with a view to rehabilitation) and three central prisons (for people serving long-term sentences, with a view to security). Of the eight prisons, two of them also house women and one of them only houses women.
} 
The intention of this initial sociological study on the religious phenomenon in French prisons as a whole (Béraud et al. 2013, Rostaing et al, 2014) $)^{5}$ is to combine approaches both focused on the sociology of prisons and the sociology of religion. It aims to explore, from a comprehensive sociological perspective (Weber 1922), the place and role which prison authorities, chaplains and incarcerated people attribute to religion, in particular in terms of rehabilitation. The point of view that is presented will therefore be centred on what happens during and not after the incarceration, nor on the possible role of associations, often denominational, with people coming out prison.

Since the very introduction of penal prisons in France, at the time of the French Revolution, the legitimacy of a sentence rests on the principle of a "good sentence" which, in addition to providing for the protection of society, will enable the delinquent or criminal person to be transformed through, among other things, labour, discipline or religion. It is in line with optimistic philanthropic theories, which believe in man's capacity to change, even those who have committed a crime ${ }^{6}$. Opinions in the eighteenth century varied on how this moral healing could be achieved. Some advocated complete isolation, others silence, some labour (forced or not, paid or not), others reflection with a focus on religious guidance, while others again championed education, which then, however, harkens back to the idea of amendment. "Rehabilitation" is the term that is then used to describe efforts aimed at transforming prisoners, in order to "straighten" them or morally "heal" them. Chaplains therefore appear as being able to effectively contribute to the moral reform of prisoners. Already in the 1870 's, however, a number of observers seem to concur on emphasising the ineffectiveness of chaplains in the moral reform of prisoners: "Instrumentalised, misled, discredited even, the chaplain emerges from this picture as a weakened figure" (Artières 2005, p. 197). It is precisely at the time when they are going through a crisis of legitimacy that chaplains are confronted with two waves of secularisation in prisons, which occur between 1880-1889 and then in 1900-1908 (Langlois 1984). Despite this reference to secularisation, from an historical point of view, there is a strong connection between Christianity and prisons, a connection which associates ideas of amendment or of rehabilitation. The idea of moral transformation, however, gradually mutates into a more prescriptive idea, with connotations of rigor and

\footnotetext{
${ }^{5}$ This research about the religion in prison is published by Presses Universitaires de Rennes De la religion en prison (2016).

${ }^{6}$ In 1791, Pelletier de Saint-Fargeau wanted to turn prison into a space and time for social re-acquisition, "the purgatory for those who have lost their way, a temporary necessity, while waiting for the school of the Republic, as well as fair and equal laws for all, to enlighten the people, and render these repressive institutions obsolete " (Petit 1990, 9).
} 
discipline. It becomes a question of cutting the delinquent away from his pathogenic environment in order to curb his amoral instincts, to keep him constantly occupied to instil good physical hygiene or to apply strict rules to favour good behaviour or respect for a way of life in accordance with religion. With the increase in the number of professionals, reintegration is the term most frequently used in the Code of Criminal Procedure. This refers to the preparation of convicts for release from prison and their ability to adapt to a new life by finding a job and place in society. If the concept of rehabilitation refers back more to the work of chaplains, the notion of reintegration is more linked to social workers who fulfil their mission within the Prison Integration and Probation Service (SPIP). Yet the reintegration mission is a by-product in relation to the security mission within French prisons, even though the former mission is what is meant to give the system its entire coherence. For example, the institution employs five times more wardens than social workers, who also manage the follow-up process in open environments.

In this context, what role does the prison administration attribute to religion in general and to chaplains in particular in reintegration issues? To begin with, we will first present the specific French framework with its peculiarities and the rather marginal position occupied by religion in prisons as well as the meagre means allocated to chaplains. We will then explore the different stances adopted by chaplains, whether they be universalist, secular, denominational and occasionally moralistic, none of which are mutually exclusive. Then finally we will analyse by which process religion can constitute a biographical turning point and sometimes help convicts to change one's criminal attitude.

\section{The context of prison secularity: low ambitions in matters of reintegration}

It is in accordance with the principle of secularity, deriving from Article 1 of the Constitution, that religion is taken into account by prison administrations ${ }^{7}$. Secularisation, much more than a legal principle, refers to a specific conception of a public regulation of religion, which is the legacy of a turbulent history. Although, historically speaking, the 1905 secularisation law contributed to restricting the rights and means granted to chaplains, today it is used to respect the principle of equality and the rights of religious minorities to practice their faiths.

\footnotetext{
${ }^{7}$ The principles of the law are presented in the two first articles: The State guarantees freedom of conscience and ensures its impartiality with regard to citizens.
} 


\subsection{French singularity}

This is manifested through the rather marginal status granted to religion and its representatives in prisons, which is reflected in the poor resources allocated to them and by religious actors being represented more as external participants than partners. Nevertheless, the 1905 law has not severed the strong link between prisons and Christianity (Liwerant 2006). The architecture of old establishments and the presence of chapels - even if many of them have been converted into cells - are proof of this Christian past (Rostaing, Galembert, Béraud 2014). Another important trace of this Catholic heritage is undeniably to be found even today in the presence of a few nuns working in women's prisons (Rennes and FleuryMérogis), paid by the directorate. Inside women's prisons, nuns have also played a moralising and rehabilitative role. The Amor Reform in the 1950s then facilitated the vast entry of diversified personnel (teachers, medical staff, paramedics, social workers) as well as people from civil society (cultural representatives, chaplaincy members, visitors), each of them fulfilling a rather positive function, focused on the rehabilitation of the person, which occasionally fuels an element of competition between them. The role of chaplains has been significantly reduced in this field.

Another French peculiarity manifests itself in the difficulty of finding a place for new faith groups. Six faiths are officially recognised (Catholic, Protestant, Muslim, Jewish, Orthodox and Buddhist) and are permitted to propose religious activities that come in addition to social activities available in prison. The taking into account of this new pluralist religious landscape often turns out to be more restrictive in comparison to prevalent trends in European countries or the United States. The manner in which religion is treated in French prisons distinguishes itself by a kind of minimalism, which is often reflected in the random character of worship facilities in prisons, the poor status and low remuneration of chaplains, as well as the limited cooperation between prison administrations and religious figures on reintegration issues. The places allocated to worship have often been forgotten or sacrificed for the sake of rationalising space in prisons which, due to the increase in the number of inmates, is in great demand. The wave of construction initiated by the 15,000 (places) Plan, launched in 1987, did not include provisions for worship spaces. The "13,000" Plan, launched in 2002, reflects a better taking into account of religious elements by providing multi-faith places of worship, although they are very small and require arrangements to be made between different religious groups. According to our study, religion in prisons is a fairly minority phenomenon, even 
though we do not have any statistics on religious practice, since statistics of this kind are forbidden in France. In this regard, the absence of religious and ethnic statistics in France is one of the republican traits which contributes to the difficulty of evaluating the needs of faith groups. This also applies to the status of prison chaplains, which is far less favourable than in England and Wales where there are not only many chaplains, but they are civil servants who are well paid (Beckford and Giliat 1998). However, a significant increase is to be noted in the number of prison chaplains, which has doubled over the past 15 years, an increase which by far outstrips the growth in the prison population. This increase is a consequence of religious pluralisation, and concerns in particular Muslim chaplains, although also ministers of older faiths have been increasingly appointed ${ }^{8}$. The management of this plurality represents a challenge for prison administration, which in accordance with the 1905 law, must ensure nondiscrimination in the free exercise of religion. Does this particular context offer prison administrations an opportunity to increasingly envisage religion as a vector of reintegration?

\subsection{Religion not conceived as a vector of reintegration}

The issues of the connection between religion and reintegration in the prison framework have barely been investigated in France. Moreover, when it comes to the adjustment of sentences, the invocation of one's religion as evidence of moral reform does not have the same positive effects it has on the other side of the Atlantic. There is no mention of the issue of religious practice in the activity reports of the Prison Administrations Directorate between 1950 and 1998, which nevertheless review aspects of prison life, which are deemed relevant to reintegration, such as educational, socio-cultural and sporting activities. It was not until 1998 that half a page was devoted to "religious activities" for the first time: ten lines under the heading of "context" recall the great principles of the Code of Criminal Procedure (CPP) and deal with chaplains in the "spiritual assistance" section of a chapter devoted to "preparatory actions for the reintegration of convicts". Another paragraph limits itself to listing the numbers of chaplains. There is no evidence up until then of any kind of policy to take the religious element into account in prisons. From 2007 onwards, however, the annual activity report from PA Directorate is substantially enriched because an entire page (p. 44) is now devoted to the issue under the heading of "access to religion". The editor insists on the "triple obligation" : neutrality, the establishment of access to religious practice for the members of

\footnotetext{
${ }^{8}$ Between 1991 and 2011, the number of Catholic chaplains rose from 230 to more than 600, whereas the number of Muslim chaplains increased from 23 in 1990 to 66 in 2006 and more than 150 in 2013.
} 
the prison population who are unable to exercise their religious freedom and to resist all forms of proselytism and sectarianism ${ }^{9}$. Prison administration distances itself from any involvement in religious life and endeavours to control excess. A brief presentation of the principal religions now forms part of the training of prison wardens, who are thus initiated into respecting religious practices.

The manner in which religious actors intervene in the field of reintegration has also been impacted by prison secularisation. Even though the provisions of the Code of Criminal Procedure regarding chaplaincies appear under the preparation for the social reintegration of convicts section, suggesting that chaplaincies can facilitate reintegration, there is no mention, however, of any concrete actions which these religious actors might specifically undertake to meet that objective. This void leave it up to pluralist associations to set up actions for the maintenance of social bonds, vocational training or access to employment or the housing of people coming out of prison. Only a few of these various associations claim any clear denominational identity or close links with Catholic chaplaincies. As a whole, they provide material help to destitute people, endeavour to limit isolation by visiting prisons and exchanging correspondence, and offer teaching in prison or accommodation for those being released from it. Even though each chaplaincy works in liaison with selected partners, there is no global "reintegration" action programme that has been organised or structurally coordinated to prepare and support inmates before their release and return to civilian life and, in the long term, their release from prison.

From that point of view, this concept of the participation of religious actors in reintegration has strictly nothing to do with what may happen in the countries of, among others, North America where faith-based prison programmes (activities promoted by religious associations) have developed considerably since the Bush administration (Damner 1992 ; Sundt and Cullen 2002 ; Kerley et al. 2005). Broadly speaking, at the request of the Federal Government, these programmes consist in delegating the prison sentence mission to religious actors. The religious organizations thus become responsible for the prisoners that request it and follow up on this monitoring even in the post-prison phase. Here we find a symptomatic manifestation of the strong link that persists between religion and rehabilitation in American penology (Ignatieff 1978). The term "rehabilitation" with its religious connotations suggests that the 
prisoners could be changed morally, after being subjected to a specific regime ${ }^{10}$.

Numerous studies have been conducted in the United States in an attempt to discuss or measure the effectiveness of these faith-based programmes, in order to ascertain if they reduce recidivism (Johnson et al. 1997); if they facilitate rehabilitation (O'Connor and Perreyclear 2002) or reduce deviant behaviour in prison (Camp et al. 2006). According to the authors, upstream religion would tend to prevent the commitment of a crime and the faithbased programmes offered to prisoners during the terms of their sentences tend to help to avoid the commitment of offences in prison and reduce recidivism on re-entry, and favour social reintegration. The idea, even though it is far from proven, that religion protects against crime and delinquency ${ }^{11}$, and that it favours desistance, i.e. the halting of a delinquent path, is very much alive. This issue is rarely raised in France. Only one book compiled by M. Mohammed (2012) raises the issue of exiting delinquency, without establishing a direct link with religion. Reference to religion is only made in two articles ${ }^{12}$ whereas reintegration through employment or life as a couple seems to be the most frequent option.

\subsection{To the personnel: Religion appeases, but does it contribute to reintegration ?}

In the field, however, our investigation noted that religion enjoys a certain legitimacy and even receives explicit recognition for some form of social usefulness. Secularism in the prison world is distinguished by a form of appeasement and pragmatism, which distances it from the ideological debates and tensions that can be observed in other types of public institutions, schools in particular. This is evident in particular in the topos of "any religion that appeases" which manifests itself in a kind of bureaucratic common sense with regard to it. As far as the prison personnel are concerned, "Anything that can help and calm the prisoners helps us too...".

\footnotetext{
${ }^{10}$ Pursuant to Quaker philosophy, one of the major objectives of confinement was penance through the required study of the Bible and reflecting on one's sins, particularly through religious education courses (Clear and Cole 1997).

${ }^{11}$ There is an entire literature with behaviourist leanings and not exempt of normative considerations, which endeavours to gauge the impact of the religious variable on delinquency and the behaviour of prisoners during and after their sentences. These investigations, mostly quantitative, conclude that the prisoners who are the most engaged in religious activities during their imprisonment are the least exposed to recidivism.

${ }^{12}$ See Calverley Adam, Farrall Stephen, "Individu, famille et communauté: des sorties" ethnoculturelles" de la délinquance?" and M. Mohamed "Schémas de sortie de bandes : de l'usure de la rue à l'ouverture sociale" in M. Mohamed (2012)...
} 
But in what way can it participate in the rehabilitation of prisoners? Wardens talk more about the logic of maintaining order through religion. The positive influence of religion is hailed for its effects on prison life. Therefore they say things like : "keeps them occupied on Sundays" (worship is often the only activity on weekends), "it calms them" ; "religion does them good". But the statements of many of the personnel during the course of our investigation reveal their doubts on the authenticity of the religious beliefs of prisoners. To them, "if they really believed, they wouldn't be in there..." Religious belief is considered to be a convenient faith, an illusion entertained by the prisoner who thinks it will fix everything, that God will help them keep in check. The personnel's criticism is most often targeted at the Islamic faith, at those who "think they can become virgins again through prayer and can't even manage to complete the ramadan". In addition to this criticism, they mention the issue - mainly in relation to the Islamic religion - of proselytism and the radicalisation of certain prisoners.

Religion can therefore catalyse tensions between prisoners and the personnel. These tensions often concern "lay" wardens (of the Gallic category, fierce supporters of secularity, for example) who feel that "there's too much religion about in the name of freedom of religious practice." These staff members then criticise the space that is allotted to denominational activities, a space that is growing, and adding to the workload. The development of other cultural activities seems preferable to them and vocational training is deemed to be more useful than religious practices in matters of social reintegration.

There is, however, recognition of some social usefulness of religion, even though this is more on the grounds of security than from the point of view of reintegration. Some staff members, many of whom are believers or practising wardens, would therefore have a greater tendency to evaluate the influence of religion on prisoners. With the backing of testimony, they even attribute long lasting changes to religion, transformations that can lead to a new relationship with the prison institution. It can even be a source of personal rehabilitation by virtue of the ethical and moral points of reference that it can give prisoners, thus enabling them to put their lives back into order, to give them a meaning, and to even project themselves into the future. Religion is considered to be a moralising tool that should have a beneficial effect on reintegration and the prevention of recidivism.

However, wardens insist on the fact that religion only interests a small portion of the prisoners. A number of them express their doubts on the durability of the religious fervour 
beyond the prisoners' release, and have little faith in the potential role of religion in matters of reintegration. The fact that religion is not explicitly conceived of as a vector of reintegration by the institution and its personnel does nor mean that it is of no value in the dynamics of rehabilitation and reintegration, particularly from the point of view of chaplains?

\section{Chaplain practices focused on personal rehabilitation}

Twenty years ago one could have thought that chaplaincies were in decline, partly condemned by the secularisation process and the professional specialisation of prison staff. Our field study revealed a developing institution and a reactivation of the function of chaplaincies with the entrance of new religions, in particular Islam. There are more than 1200 chaplains operating in French prisons. Even though Christian chaplains are to be found in the country as a whole with an average of three catholic representatives per establishment and at least one protestant per prison, this is not the case for Muslim or Jewish chaplains, who often have to spread themselves between several establishments or for the newly integrated religions that still have few chaplains (in 2013, for example, there were: 4 Buddhist chaplains in French prisons as a whole) ${ }^{13}$.

An ethnographic approach enabled us to observe chaplains in their working context and in action (in their places of worship, in cells, corridors, at meetings, and in training sessions), and this enabled us to gain a better understanding of how they define their mission.

\subsection{Humanising agents, but not in charge of reintegration}

The chaplain is a person who is not a member of the prison staff, he/she is a civilian and "external" figure to the prison world, while moving freely through prisons since he/she has keys to cells in most of the establishments. He is often seen as an impartial figure, devout, and often benevolent. He is a resource as a person who can bring information, goods, spiritual or social assistance, but above all, a presence, as Jean-Bernard puts it:

"To be a chaplain is above all to be a presence in the broadest sense of that term. (...) We're there for them, we're there for free. We have to be available to go see them in their cells, listen to them." (priest, jail1)

\footnotetext{
${ }^{13}$ Catholic chaplains represent $54 \%$ of all chaplains, Protestants $24 \%$, and Muslim chaplains $10 \%$.
} 
Chaplains have often valued this free listening, which differs from that of other professionals. As Jean-Paul (Catholic chaplain, jail2) points out, they have the time: Thus they can "spend five minutes or two hours in a cell with a prisoner." Their mission, however, is difficult to determine. It is not clearly defined in the Code of Criminal Procedure, as Pierre-Paul explains:

"I would say that the Code of Criminal Procedure sets a clear framework. It states clearly that the chaplain is neither a psychologist, nor a social worker, nor a warden, nor a judge, nor a friend. He is there to provide spiritual and moral support. How can that be put into practice? I realised that it was very easy to break out of the framework. You can very swiftly feel the urge to be a social worker. Which is what I did when I wanted to find work for a prisoner who was about to be released... And in doing so, I overstepped my function." (Protestant chaplain, prison1)

Chaplains therefore have a different role to those of social workers and therapists. It is therefore a question of avoiding any competition or indeed conflicts with other agents and professional, to find one's "right place" in the division of labour. Thus, Marthe undeniably feels a certain pride for the appeasement she manages to provide, from the blessings she gives to the prisoners she visits, including those who suffer from psychological or even psychiatric disorders. However, she takes care to ensure she places herself on another level to that of the psychologist. Similarly, Roger, the Catholic chaplain in the Maison Centrale prison (MC2) considers "the issue of reintegration is one we deal with without it being ours". According to him, the chaplain does not provide any "concrete help", but through his work he contributes to "the rehabilitation of the person". On talking about her long experience as a prison chaplain, Isabelle Le Bourgeois (2006, 133-134), above all sees herself as a humanising factor and refuses to take on the responsibility of reintegration:

"First of all, we are not responsible for the reintegration of prisoners when they leave prison. Nor do we have any explicit responsibilities as nurses. That's not exactly our task. We are there in the name of the Gospel: "I was in prison and you visited me", Jesus said (Mt 25, 36). Our intervention is therefore aimed at helping people to rediscover that part of humanity which is temporarily or long-lastingly enclosed behind walls, the part experiencing profound human misery and which reveals the power of evil present in all of us in a more visible way."

Above all, chaplains offer a non-bureaucratic relationship within the prison organisation (Becci 2012). "We see the prisoner as a human being, not just a number in the register or a 
file", one pastor insists. Therefore, in the eyes of the inmates, they are defined and perceived as re-personalising and humanising figures, by re-including the prisoners in a joint humanity:

"The chaplain is a person who is sent into prisons to meet prisoners, to share a piece of humanity with them, rediscover a common dignity as children of God and tell them that salvation is for all of us." (Bernadette, regional Catholic chaplain.)

According to this presentation, we get the impression of a meeting without any stakes. Thus, according to the national Catholic chaplain, the approach to spiritual assistance is a "a free meeting without any stakes, without any obligations for results." Behind these general terms, there is a great diversity of professional practices among chaplains in terms of their clientele and mission definitions.

\subsection{Occasionally moralistic stances}

A high number of chaplains endeavour to be impartial in their actions: Not to judge, to be prepared to hear everything. They insist on the horizontal nature of the relationships they have with prisoners. And in a significantly different way, others veer towards a more vertical and top-down stance of a normative and moralistic nature, as a continuation of the educational role. They therefore often appear as teacher-chaplains, in reference to the figure of the Imam teacher (Jouanneau 2011) who is in charge of ensuring the prisoners' good knowledge of religion. This is how Karim and Marouan, both of whom were trained in the Great Mosque of Paris, describe their roles, in particular with regard to incarcerated people, who start to practice their religion again after having lapsed for a long period. A very good example of this kind of evolution is to be found in young people of North African origin, who have abandoned the practice of their faith, often during their adolescence, and then return to Islam. Having noted the poor knowledge of the young inmates they meet, the chaplains aim to offer them a basic religious socialisation but also, for Marouan, to combat interpretations which they deem to be false and even to teach laicity. Both of them devote a part of their services to giving lessons and aim to promote the practice of a moderate form of Islam. In this way they also contribute to controlling certain forms of radicalisation, but more mundanely their mission involves teaching inmates how to read the Koran, pray, do ablutions and to initiate one's self in the duties of a Muslim.

"The regional chaplain told me: "Broadly speaking, our goal is to teach inmates how to 
pray, do ablutions, simple things. How to pray in groups. In other words, the basics: That's how I function. I already know that if an inmate manages to pray correctly that's already not bad. On top of that they're there to learn, it's not to go into any depth." (Karim, jail1).

This more moralistic stance is also reflected in conversations. This is the case of the Protestant chaplain in MA3, a former teacher, whose leitmotiv to the recidivist inmates he visits is the following: "Shouldn't you just take out a subscription to prison and finally decide to put an end to all this bullshit!" Chaplains therefore appear as being able to effectively contribute to the moral reform of prisoners. Thus they participate in the mission to reform the prison population. According to Farid, on the basis of the motivations of Muslim spirituality, it is a case of disseminating an ethic that is designed to get the inmate back "on the right path":

Our mission is religious and educational. Because religion is a way of educating people (...). Yes, it's a way of educating people (...). Because religion prohibits us to steal, hold people up, it forbids us to drink alcohol to avoid all our problems, forbids us to sell drugs, leads us to respect our neighbours, respect the elderly... Religion - not just Islamic religion but all religions - pushes us to respect others and to respect ourselves. (Farid, Muslim chaplain, prison2)

Chaplains' statements do not always allude to a direct reintegration mission, even though they may contribute to it on the sidelines, and the presence of the religious element in prisons appears as a sign of the failure of the re-socialization project. Chaplains participate in the personal rehabilitation of inmates, a vital stage in the social rehabilitation process due to desistance. Their solicitous approach places them on a level at which prison professionals have largely failed: To open up to "the possibility of forgiveness (...) the fruit of a possible renewal" (Caillé and Fixot 2012, 8). It is a question of giving a meaning back to life, even to those who have committed serious crimes in order to enable inmates to establish a link with the period before, during and after their incarceration. Chaplains may sometimes accept to act as character witnesses in the trial of an inmate they have followed, in order to talk about the path they have taken and to therefore publicly account for the work the person they have accompanied has done on him/herself. Irrespective of their religions, all the chaplains we met had some nice stories to tell about inmates who, through their contact, managed to reorganize and even transform their lives during the period of their sentences. But often the role of a chaplain is comparable to that of a "nurse, who in a palliative care service, gives out medication that eases the pain without curing the disease." (Le Bourgeois 2006, 9) 


\section{Religion as identity support for the prisoners}

Imprisonment entails an upheaval for the inmate: It is an ordeal, a painful experience, which distances them from normal social life, an experience one does not emerge from unscathed. It marks an interruption in the ordinary course of life and implies diving into a totally alien world. It means a lot more than the simple deprivation of freedom: It results in the deprivation of belongings, heterosexual relations, autonomy, and even security (Sykes 1958). Incarceration entails a triple ordeal. On one hand, the inmate is subject to an enveloping institutional take over within a restrictive organisation. This organisation imposes a limiting spatial/temporal framework on the inmate and strict regulations. It maintains people in a position of permanent subordination with a prolonged loss of responsibility, which may result in a certain inability to assume ordinary responsibilities. Being arrested, incarcerated and sentenced can, on the other hand, undermine a person's sense of identity: By being perceived differently by other people, they perceive themselves differently as well (a feeling of degradation). Finally incarceration and prison conditions constitute an infringement on dignity due to the impossibility of maintaining any intimate spaces (Rostaing 2006, 39).

Religion in a prison environment constitutes a personal resource and a shield to protect one's self from others. It also represents a right for prisoners, the right to practice their religion freely, which the prison administration must guarantee. It brings instrumental or useful benefits, such as the search for security, material comfort, access to external people or to social relations (Clear et al. 2000, 64-69). It offers a structuring framework, which facilitates life in prison, an opportunity to rehabilitate one's self through forgiveness can even be a vector of change with a view to reintegration (Sarg and Lamine 2011).

\subsection{Religion as a structuring framework}

Imprisonment therefore constitutes a moment of reflection which, often through the encouragement of close ones, leads to "re-forging the path towards God", finding the "right path" again and rejoining a spiritual tradition. Our investigation revealed that this resource is mainly used by those who have had a religious socialisation. A large number of people who have undergone religious socialisation then report an intensification of their religious practice in prison; others renew their faith. The profile type of this category of re-convert is that of a young person educated in a religious denomination or people from a diversity of cultural 
and/or religious backgrounds who say they become interested in religion for the first time in their lives. Their delinquent and even criminal paths partly explain this realisation and this resolve to be seen "in a good light" by the family that supported them during their imprisonment and as a token of their desire to be reintegrated. For a lot of them, religion seems to constitute a "lifeline": Support that enables someone to stay alive, to prevent themselves from sinking into the depths of despair, and to "cling back on to something". It can often intervene in the re-ordering of one's life in a process in which it is not so much the outcome as the vector and instrument, by enabling the person to, for example, define stages and personal objectives. On this point, Dammer (2002) mentions the hope which religion can give rise to for people who are imprisoned, by giving them a sense of direction, goals to be reached. The progress achieved in terms of religious knowledge is highlighted by the followers as a way of emphasising the efforts that have been made and the path that has been followed. Hakan, a 23 year old man of Turkish origin and a re-offender serving a 3 year sentence for armed robbery, has assiduously started to practice his religion again for the past seven years. He likes measuring his progress by learning new and increasingly difficult surahs every day.

Religion, with its rites and prescriptions, also organises their relationship with time. From a structuring point of view, it helps to keep one going in prison, to overcome the daily frustrations linked to the pressures of imprisonment and even to find "a certain peace of mind" (Dammer 2002, 41). For some, it is a way of learning "more civilised behaviour, such as a positive attitude, politeness, humility, calm and self-control" (Dammer 2002, 42). The occupational and pacifying virtues of religious practice contribute to the acceptance of the punishment and a reflection on the acts that have been committed.

Meetings with chaplains are sometimes the only social link in prison, particularly for the most isolated inmates. The chaplain, who is a reminder of the common humanity they share, contributes to a personal revaluation and participates in a re-personalisation. The 46 year old Jules, who was a Protestant since his youth and a devout follower felt he "wasn't worth anything" after he received his 20 year prison sentence for crime. Having served 17 years in a jail, he feels rehabilitated through his relationship with the Catholic chaplain:

"It's Robert, the old Catholic chaplain who suggested I come along. Initially I was very surprised by this openness because I'm not a Catholic. I was very close to him, he saved me in a way. Thanks to him, I was able to pull through difficult periods. We 
could confide in him, always looking out for others, that hope. When he preached, we felt it really concerned us. He understood the weight of a prison sentence. Afterwards you feel like you're worth something, that you can still get out of this place and lead a normal life with some peace."

Spirituality can, in fact, act as an instrument for the reconstruction of an identity at times when the self is threatened, it can be an element of identity (not the only one) to counterbalance the stigma of prison and being an ex-convict. It can enable people to regain a positive image "for one's self" and for others, which is the first stage that is sometimes necessary for those who have committed "hideous" crimes or who consider themselves as monsters. The belief in a "fundamentally good self" is in fact one of the three essential criteria which encourages desistance, according to Maruna $(2001)^{14}$.

\subsection{The rehabilitation of the self through forgiveness: Spirituality and sin}

The invocation of a god who saves also provides a way of finding one's feet again and regaining some form of moral dignity that one thought had been irremediably lost. It can help prisoners to escape the stigma of monstrosity, of an amorality or immorality that excluded them from the community of mankind. It enables them to come to terms with their moral failings, as Marie-Thérèse, a 61 year old Catholic and mother of seven, who has served 4 years, testifies. She says she has "laid down her sins" and feels lighter: "It did something to me, it's as if a weight lifted from me. That night I slept like a baby."

There may be an explanatory key in the fact that the evocation of the Final Judgement is frequently mentioned in discussions with inmates, whether they be Jewish, Christian or Muslim. The fear of hell is, in fact, a recurrent theme, in the discussions of certain inmates.

Gloria, a 22 year old woman of Brazilian origin, who claims to be a Catholic but was socialised as a Pentecostal, and who very brutally murdered a close one, seems to be more concerned with the issue of salvation than her upcoming trial. In view of the crime she has committed, hell seems inevitable:

I'm in jail because I didn't want to listen to all those church people, not only my mother... My mother says: God can forgive everything. But I took someone's life, the life of one of God's children. I don't think he can forgive me. I go to church. I pray. I

\footnotetext{
${ }^{14}$ The three criteria are: The belief in a "fundamentally good self", the feeling of mastering one's destiny and the desire to be useful, particularly among young people.
} 
tell myself I'm going to burn in hell. It's very difficult to live with that. Sometimes I crack. At night we're alone in our cells. You feel like doing yourself in. Even I'm afraid of myself.

The nature of the offence or crime committed undeniably weighs on any potential need to rehabilitate one's self through forgiveness. It is significant that the most ardent followers in the clienteles of chaplains are the authors of sexual attacks ${ }^{15}$, who are considered by their fellow inmates as "sexual criminals" or murderers who have committed "hideous" crimes. The latter became scapegoat figures (Chauvenet, Rostaing, Orlic 2008) and even though participation in religious practices may not erase the identity of a paedophile, it more or less neutralises the reactions that this identity can give rise to (insults, violence, aggression). Even though this may be some form of "positive illusion", its performative effects are undeniable. Religion therefore offers a cognitive space, which reshuffles the cards, not only in relation to one's self but also in relation to others. Frequent talks about "restarting from scratch" seem to facilitate the conversion of convicts with heavy criminal records. This repentance dimension is particularly valued by Muslim inmates. In the words of some, settling one's religious duties can be a way of "wiping the slate clean". The force of this use of religion can be gauged from the criticism it gives rise to among the personnel and social workers, who see it as a slightly easy way for some convicts with long sentences to shirk their responsibilities and even cultivate a form of denial.

For others, religion can contribute to tough introspective work. "Before I didn't know what was evil". The 44 year old Yves in a jail who was sentenced to 25 years for rape, converted to Islam five years ago, a conversion which he experienced as a rebirth process in the eyes of God. He feels he has spent his life in jail ("I was in jail at the age of 18, came out at 35. I came back at 35 and I'll be out at 60.") and describes the path he has followed as "a huge journey" (both religiously and therapeutically) during which he learned to differentiate between good and bad and to think of his victims and no longer just his "own pleasure".

The ordeal of prison can also be reinterpreted as a spiritual penance and no longer as a penalty imposed by man. According to Aurélia, a 45 year old of Italian origin, the fact that she has been put to the test by God by being imprisoned has enabled her to recognise her wrongs.

\footnotetext{
${ }^{15}$ Clear, Hardyman, Stout, Lucker and Dammer $(2000,64)$ also mention the presence of authors of sexual offences in Christian chaplaincies in the United States: "The sex offenders show up in the Christian group too so they won' t get hurt. They need to get protected. "
} 
Educated as a Catholic "through family conditioning" to use her own words, she then moved away from religion and committed scams for which she has asked God's forgiveness in order to be at peace with herself.

\begin{abstract}
"So now I can say I no longer look for excuses for my faults. I know where I went wrong and I no longer have any problems asking for God's forgiveness when I make mistakes in my life. God has helped me a lot to find some peace in myself. I thought a lot about the fact that it's too easy to go and pray when we're in need and then, when everything is going well, to forget to thank God for that. I admit it was very tough in the beginning, but I think it was Him who helped to put up with a lot of things. Now I'm no longer anxious, I feel good inside my head. It's positive in any case. And I think without this experience I probably would have continued along the same... path I had taken recently. And that's also when I said that "if I'm here it's because God agreed to it". Maybe... in the end, it's a gift. Prison arrived and I have peace."
\end{abstract}

In addition to realising one's errors, religion can offer the means to take on another path. Many inmates use metaphors such as "tortuous path" or "wrong track", counterpoised against " the right path": As the 28 year old Younès, of Algerian origin, who received a Muslim education and started practising again in prison, says: religion can bring one back to the "right path". Having been imprisoned in a jail for the fourth time for theft, he has the feeling that God can enable him "break out of the deadlock".

\title{
4.3 Is religion a vector for changing one's self?
}

For some inmates religion has represented the prospect of a self-transformation in the longer term, which initiates a life change associated with a probable exit from delinquency. This deep change occurs through some real work of reflection on one's self and one's path, and it requires the realisation of one's responsibilities and the will to give one's life a meaning, as explained by the 25 year old Leilla, who is serving a 7 year sentence for violent theft. She talks about how, after a period of isolation which enabled her to realise the gravity of her actions, religion helped her to assume her responsibilities and gave her the desire to "become a good person". As the offspring of a mixed couple - a Christian mother and Muslim father - she was certainly baptised as a child, but she says she "has always felt drawn to the Muslim religion". The path to her conversion predates her incarceration, but it was in order to "access forgiveness" that she took the step in prison and that she now knows who she is and where she wants to go: 
Religion enabled me to, for example, see the bad that I'd done, the act I'd committed, to gratuitously attack people for money, it wasn't me. And I learned, in fact, to put myself in other people's shoes. To put myself in victims' shoes. To understand, try to understand, not to see myself as a victim, far from it, but try to also understand what I would have felt as a victim. That meant that I felt really bad, I felt really bad in my own skin. In fact, after feeling that, I wanted to try to change, try to become a decent person because all religions advocate good and not evil. In fact, it enabled me to understand where I was and to live it too, with that new little space that had just opened in my brain, to know who I am and where I want to go. It's true that it's more difficult to become a good person than it is to do evil.

"Becoming a good person" after having done bad things requires a profound change which religion can contribute to, through the reading of texts on the meaning of life, prayers or conversations with chaplains. It constitutes a "source of norms and values, it helps the inmate to structure or restructure his or her life" (Sarg and Lamine, 2011, 101). Denominational commitment constitutes an enriching identification model, which offers a new path for getting out of delinquency, whether it be Christian (Giordano et al. 2008) or Islamic (Calverley et Farrall 2012). It is a question of breaking habits, making friends in other communities, breaking away from "bad company", maintaining or even renewing links with one's family, showing one's change of behaviour to one's close ones and demonstrating one's resolve to get out of it.

These recurring discourses on following the right path, not coming back to prison, doing good, were particularly frequent in the jail, the type of establishment where activities, training and work are rare and where the attendance of religious services is the highest (compared to penitentiaries). They are also the detention centres in France where there are short sentences ${ }^{16}$ and where the recidivism rates are the highest. It is a question of "believing" in God's power to control one's bad actions, while at the same time being aware of the limits of this type of invocation. Religion is therefore associated with a hope, that of managing to persist over time, by defining a stricter framework and practices.

Sami, a father of three, who was given a two year sentence for a drug case, says he is increasingly interested in religion. This 38 year old Franco-Tunisian, who is a non-practising

\footnotetext{
${ }^{16}$ In the three jails (maisons d'arrêt) that were studied, half of the inmates were serving a sentence of less than one year. The turnover of the penal population is particularly high there.
} 
Muslim and drove his father to the mosque for eighteen years without ever entering the building, promised himself that when he gets out of the jail he will go to the mosque with his father and practice.

Some inmates, who consider the cessation of their religious practices or their distancing from religion to be the original source of "their problems", believe that their coming closer to God will act as a protection for the future, "to get out of the bad life". In the words of Roger, a 38 year old from Martinique, who was sentenced to 18 years for a crime and has served 8 in a jail:

"My aunt wanted to bring me back closer to God because she thinks I ended up in prison because I wasn't praying properly, that I wasn't close enough to God. I call on the Eternal One to ask him to put wisdom in our hearts. My prayers gave me a little strength, a little bit of spiritual strength. I deepen my personal wisdom. And also it can help me to get out of bad living, yes, it helps. In life you never know when you might find traps, obstacles, you call upon the Eternal One so that he'll always protect you."

Some of the inmates we met shortly before their release doubted before even being freed whether they would be able to follow the good path or not. The 63 year old Armande, who received a 25 year sentence for ordering the murder of her husband and has already served 16 years, prays in the chapel a lot and "devotes every minute of her free time to Him". She, who has always been a practicing Catholic, talks about this fear she has in connection with her release, which she expects to be in two years time: "In leaving I'm afraid I'll forget him, that I'll talk less to God.“ The 32 year old Christian, who is serving a 3 year sentence for striking and inflicting wounds with weapons, and is a re-offender known for violent behaviour and is psychologically fragile, tells us about his fear of being released, his fear of meeting "the devil", of crossing "the enemy" (the victim in the fight) who might incite him to do the irreparable. According to him, only religion could stop him from "doing bad".

The meetings we had with re-incarcerated inmates showed the fragility of commitments when returning to a normal life and how paths can be reversed. Several of the inmates that we met mentioned their poor practice of religion when they left a previous prison before they were reincarcerated. As much as they have time in prison to practice, as much as life outside seems to reassert itself and offer many temptations. 


\section{Conclusion}

During our investigation, few inmates presented religion as a means of pulling through, even though it may be mentioned as one of the possible dimensions of desistance. The people we met use religion more as a structuring force in the meaning of Sarg and Lamine (2011), and focused more on the here and now, rather than a restructuring perspective geared towards reintegration. Of course, these two perspectives are linked since, by constituting a resource for personal and even social rehabilitation in prison, religion can favour reintegration. It can, however, be noted that this perspective is limited to people who have already received religious socialization. Our interviewees are more situated in the continuity of their careers, whether they be religious or not, since there are few conversions in prison. Moreover, very few inmates evoked religion as the sole tool of rehabilitation. If it was mentioned by a few, and particularly by Muslims with the idea of putting things back into order, for example, it was associated with a slightly vague hope of personal reform without it being expressed in any concrete plan, however. Through the humane skills they exercise, chaplains in any case offer inmates a privileged space in which to reaffirm their dignity and humanity. To inmates they represent a possible resource for withstanding imprisonment or at least to endeavour to neutralise some of its degrading effects and they often contribute to giving a meaning to the sentence. There is no proof, however, that they perform better in terms of rehabilitation than other listening professionals that operate in prisons, but they contribute to it. Contrary to what happens in other European or American countries, where it is strongly linked with reintegration programmes, in France the prison authorities seem to see religion more as an appeasing resource or as a means of "withstanding incarceration", or even as tool for maintaining order, without any real ambition for reintegration. From that point of view, prison is a manifestation of the varied geometry of secularism and an excellent indicator of the ambivalences of French secularism, which sometimes represses religion as an unacceptable element in public life, while at other times, on the contrary, calling on its supposed potential to pacify souls and act as an agent of social control. These forms of religious utilitarianism betray an institutional admission of the vacuous meaning of sentences, as well as the illusory, even mythical, character of the supposed re-socializing virtues of modern sanctions. 


\section{Bibliography}

Artières P. (2005). L'aumônier, le médecin et le prisonnier à la fin du XIXe siècle, in Faure and Delpal (dir.), Religion et enfermement (XVIIe-XXe siècle) (pp. 193-202), Rennes : PUR.

Becci I. (2012). Imprisoned Religion: Transformations of Religion During and After Imprisonment in Eastern Germany, Farnham: Ashgate.

Beckford J. A, Gilliat S. (1998). Religion in Prison. Equal Rites in a Multi-Faith Society, Cambridge: Cambridge University Press.

Béraud C., de Galembert C., Rostaing C. (2013). Des hommes et des dieux en prison, Paris: research subsidised by the Prison Administrations Directorate (DAP) and the GIP Law and Justice research mission

Caille A, Fixot A-N. (2012). Presentation “leaving prison”, Revue du Mauss, n 40, 5-22.

Calverley A., Farrall S. (2012). Individual, family and community: ethnocultural ways out of delinquency ?, in Marwan MOHAMED (dir), Les sorties de délinquance. Théories, méthodes, enquêtes (pp.131-156), Paris: La Découverte.

Camp S.D., Klein-Saffran J., Kwon O. K., Daggett D. M., Joseph V. (2006). An Exploration into Participation in a Faith-Based Prison Programs, Criminology and Public policy, volume 5, issue 3, 529-550. Chauvenet A., Rostaing C., Orlic F. (2008). La violence carcérale en question, Paris : PUF.

Clear, T.R., Cole, G.F. (1997) American Corrections, Belmont (CA),Waldsworth.

Clear T., Harydman P. L., Stout B., Luken K., Dammer H., (2000), The Value of Religion in Prison. An Inmate Perspective, Journal of Contemporary Criminal Justice, vol. 16, 53-74.

Dammer H. R., (1992). Piety in Prison: An Ethnography of Religion in the Correctional Environment, NewJersey: UMI.

Dammer H. R., (2002). The Reasons for Religious Involvement in the Correctional Environment in T. O'Connor \& N. Pallone (dir.), Religion, the community and the rehabilitation of criminal offenders (pp. 25-58). Binghamton, New-York: Haworth.

Giordano P., Longmore M., Schroeder R., Sefferin P., (2008). A life course perspective on spirituality and desistance from crime, Criminology, 46, 1, 99-132.

Gotman A., (2013), Ce que la religion fait aux gens, Paris : Ed. de la MSH.

Ignatieff M., (1978), A just Measure Pain : the Penitentiary in the Industrial Revolution 1750-1850, London: Penguin Books.

Johnson B. R., Larson D. B., Pitts T. C., (1997), Religious Programs, institutional adjustment, and recidivism among former inmates in prison fellowship programs, Justice Quarterly, 14, 145-166.

Jouanneau S., (2011). "Ne pas perdre la foi dans l'imamat". Comment se maintiennent les "vocations" d'imams bénévoles en France, Sociétés Contemporaines, n 84, 103-125.

Kerley K. R., Matthews T. L., Blanchard T. C., (2005). Religiosity, Religious Participation, and Negative Prison Behaviors, Journal for the Scientific Study of Religion, 44(4), 443-457.

Langlois C., (1984). L'introduction des congrégations féminines dans le système pénitentiaire français (18391880), in Petit Jacques-Guy, La prison, le bagne et l'histoire (pp.129-140). Genève : Ed. Médecine et Hygiène, Le Bourgeois I., (2006), Espérer encore, Paris : Desclée de Brouwer.

Liwerant S., (2006). Evasion spirituelle en détention autorisée : en détention, prière de réinsérer, Droit et Cultures, $\mathrm{n}^{\circ} 51$.

Maruna S., (2001). Making Good: How Ex-Convicts Reform and Rebuild Their Lives. Washington : American psychological association Books.

Mohammed M., (2012), Les sorties de la délinquance, théories, méthodes et enquêtes, Paris : La Découverte.

O'Connor T. P., Perreyclear M., (2002). Prison Religion in Action and Its Influence on offender Rehabilitation, in O'Connor T. P. \& Pallone N. J. (Eds.), Religion, the Community, and the Rehabilitation of Criminal Offenders (pp. 11-33), New York: Haworth Press.

Petit J.-G., (1990). Ces peines obscures, la prison pénale en France (1780-1875), Paris : Fayard.

Piette A., (2003). Le fait religieux. Une théorie de la religion ordinaire, Paris : Economica.

Rostaing C., (2006). La compréhension sociologique de l'expérience carcérale, Revue européenne de sciences sociales, septembre 2006, Tome XLIV, $\mathrm{n}^{\circ} 135,29-43$. 
Rostaing C., de Galembert C., Béraud C., (2014). Des Dieux, des hommes et des objets en prison. Apports heuristiques d'une analyse de la religion par les objets, Champ Pénal, vol. XI. URL: http://champpenal.revues.org/8868; DOI : 10.4000/champpenal.8868

Sarg R., Lamine A-S., (2011), La religion en prison. Norme structurante, réhabilitation de soi, stratégie de résistance, Archives de Sciences Sociales des Religions, ${ }^{\circ}$ 153, 85-104.

Sundt J. L., Cullen F. T., (2002), The Correctional Ideology of Prison Chaplains: A National Survey, Journal of Criminal Justice, 30 (5), 369-385.

Sykes G., (1958). The Society of Captives. A Study of a Maximum Security Prison, New York: Princeton University Press.

Weber M., (1995 [1922]). Economie et société, tome 2, Paris : Presses Pocket. 